This article was downloaded by: [Memorial University of Newfoundland]

On: 10 March 2015, At: 14:22

Publisher: Routledge

Informa Ltd Registered in England and Wales Registered Number: 1072954

Registered office: Mortimer House, 37-41 Mortimer Street, London W1T

3J H, UK

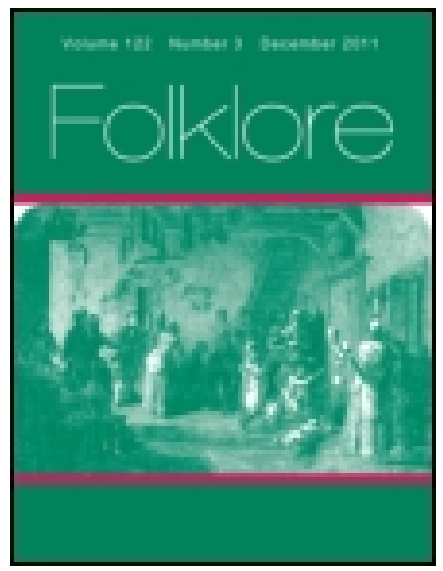

\title{
Folklore
}

Publication details, including instructions for authors and subscription information:

http:// www. tandfonline.com/loi/ rfol20

\section{Notes on Orendel and other Stories}

Professor W. P. Ker M.A.

Published online: 14 Feb 2012.

To cite this article: Professor W. P. Ker M.A. (1897) Notes on Orendel and other Stories, Folklore, 8:4, 289-307, DOI: 10.1080/0015587X.1897.9720426

To link to this article: http:// dx. doi. org/ 10.1080/0015587X.1897.9720426

\section{PLEASE SCROLL DOWN FOR ARTICLE}

Taylor \& Francis makes every effort to ensure the accuracy of all the information (the "Content") contained in the publications on our platform. However, Taylor \& Francis, our agents, and our licensors make no representations or warranties whatsoever as to the accuracy, completeness, or suitability for any purpose of the Content. Any opinions and views expressed in this publication are the opinions and views of the authors, and are not the views of or endorsed by Taylor \& Francis. The accuracy of the Content should not be relied upon and should be independently verified with primary sources of information. Taylor and Francis shall not be liable for any losses, actions, claims, proceedings, demands, costs, expenses, damages, and other liabilities whatsoever or howsoever caused arising directly or indirectly in connection with, in relation to or arising out of the use of the Content.

This article may be used for research, teaching, and private study purposes. Any substantial or systematic reproduction, redistribution, reselling, loan, sub-licensing, systematic supply, or distribution in any form to anyone is 
expressly forbidden. Terms $\&$ Conditions of access and use can be found at http://www.tandfonline.com/page/terms-and-conditions 


\section{Jfolk= Lore.}

TRANSACTJONS OF THE FOLK-LORE SOCIETY.

\begin{tabular}{lll}
\hline VoL. VIII.] & DECEMBER, 1897. & [No. IV. \\
\hline
\end{tabular}

NOTES ON ORENDEL AND OTHER STORIES.

BY PROYESSOR W. P. KER, M.A.

(Read at meeting of 16 th February, 1897.)

THE German poem of Orendel (edd. von der Hagen, 1844 ; Ettmüller, $185^{8}$; Berger, 1888 ) is a confused and rambling story, belonging to one of the lowest orders of medieval romance, the hack-work of the professional minstrels. Its date is uncertain: the authorities for the text are late, a manuscript of 1477 (burnt in 1870 , at Strasburg), and an early printed book (Augsburg, 1512). The last editor dates the poem about 1160 , but the date is brought considerably lower down by Dr. Richard Heinzel in his study of the subject ( 1892 ).

The author has combined two principal motives in his story: (I) the adventures of a king's son; he goes on a voyage to win the princess of a distant country, who is known to him only by report as the fairest woman on earth; and ( 2 ) the legend of the Holy Coat of Treves, the Seamless Coat (tunica inconsutilis), which is found by Orendel in his wanderings. The whole thing is the work of an irresponsible poet who has little qualification for his art except a command of all the commonplaces of popular romance, and the usual healthy appetite of travelling minstrels (die varnde diet, the wayfaring men, according to their old German ros. vius. 


\section{Notes on Orendel and other Stories.}

appellation), which, like the rest of his tribe, whatever their language, he is ready to confess at the most thrilling moment by stopping to ask for a drink (1.279I).

Orendel has been the subject of learned commentaries far out of proportion to the author's claims as a poet. One of the best reasons for this is the attraction of the name. Orendel corresponds to a name of some importance in Teutonic mythology : Aurvendill, Orvendill, the husband of Groa; he was brought back by Thor in a basket when Thor came back from the land of the giants; one of his toes was frostbitten on the journey, and Thor flung it at the sky, where it is a star, Orvendils tá. The story is one that lends itself to the interpreters of solar and summer myths, and naturally the German Orendel has been compared with the Icelandic story as told by Snorri. The name is found elsewhere; Horvendillus in Saxo is the name of Hamlet's father, and the Anglo-Saxon Earendel is a name by which Cynewulf addresses the Lord in a passage where Christ is the "brightest of angels," "the radiance of the sun above the stars ;" it is evidently in this case an old mythical or poetical name capable of meaning the sun, or the light of the sun (Crist, 1. 103).

Besides these mythological associations and possibilities in Orendel, there is the other motive, of the Gray Coat, and its association with the legend of the Invention of the Cross.

The story is so indefinite, and so full of repetitions and commonplaces, that it is difficult to say what its main design is, if it has any, and very easy to support different theories of its origin. It may be regarded as a clumsy mixture of an old German heroic tradition with the legendary story of the Seamless Coat. Or again, the legendary part of it, the part resembling the Saints' Lives, may be considered as the foundation of the whole, the suggestions of the name Orendel being dismissed as merely fortuitous, and the hero's adventures being taken, not as a survival of old mythology, but merely as a mass of commonplaces, which lay ready 
to hand for any professional story-teller to pick up, just as the ordinary machinery of the romance of chivalry might be used again and again without infringing any copyright. This second view is represented in Dr. Heinzel's treatise. Of the first party, regarding Orendel as an ancient German hero with a right to his name, and possibly even to high honour as a Sun-god, there are different advocates, the most thorough-going representative of this view being Müllenhoff, who is followed by Berger in his edition of the story. Another view, but one which at the same time recognises a line of native old tradition in Orendel, is given by Rydberg.' Grimm puts together the Aurvendill-EarendelOrendel references without trying to reconcile the evidence, still taking the name Orendel in its mythological bearings. Ile calls attention also to the things resembling the Odyssey in' the shipwreck of Orendel.

These are some of the incidents of the story :-

King Ougel of Trier had three sons; the youngest was Orendel. It was on St. Stephen's day that he was knighted; he asked his father to find him a wife. His father told him that he knew of no match for him but one, who was a queen over sea, wise and glorious-Bride, the Queen of the Holy Sepulchre :

$$
\begin{aligned}
& \text { Si ist ein edal kunigin hare } \\
& \text { Und ist gesezzen vil ferre } \\
& \text { Ubber des wilden sêwes fuot, } \\
& \text { Si ist ein edele kunigin guot. }
\end{aligned}
$$

Orendel set out on the voyage with seventy-two keels. They were driven into the Klebermere-more correctly Lebermere, the sticky or curdled sea (la mer betee), which, according to some, lies over the drowned island of Atlantis." Orendel's ships were kept there for three years. They got

1 Teutonic Mythology (Engl, tr.), p. 566 sqg. Orendel is equated with Svipdag, and the princess with Freyja, according to Rydlerg's interpretation of the Svipdag myth, which has been aummarised by Mr. York-Powell, introduction to Saxo, p. exvif. sqq. (F. L. S. 1894).

"Image du Mtonde, quoted by W. Michel, Fiergw, 184t, p. 287 . 


\section{Notes on Orendel and other Stories.}

free, and were in sight of land and of the Holy Sepulchre when they were blown to sea again and wrecked. Orendel was saved on a piece of the ship; his clothes were torn off among the rocks and breakers, as he was thrown on a desert shore. There he made a shelter for himself in a hole in the sand. On the fourth morning a fisher came sailing by, and Orendel cried to him for help, and was taken on board, calling himself a shipwrecked fisherman, and, like Ulysses, taking a leafy branch to cover his nakedness. He was put to the fishing by his master Ise, and acquitted himself well. The Gray Coat was found by Ise the fisherman in a whale that they had caught, and was sold to Orendel for $3^{\circ}$ pence (provided by the Angel Gabriel). Orendel, later, went off by himself, helped by the fisherman and his wife, and came, after adventures, to the city of the Sepulchre. There the Templars took no notice of him; one of the citizens called him "Gray Coat," which became his name, and pointed out Bride to him. Orendel was vexed at his want of a horse, but got a horse and shield from a heathen king Mercian. Brîde saw him, and sent a messenger to ask him to enter her service. The Templars were jealous, and sent for a giant on an elephant to come and take Orendel's life. Orendel knocked him off his elephant (calling the beast a sea-cow), and thereafter routed twelve kings, and came back into the presence of Bride, who asked him if he was King Ougel's son, her destined lord, but he refused to acknowledge this. Then more heathens and another giant have to be disposed of. The Queen gives Orendel her father King David's sword, and after the battle says she will have no man but Gray Coat. Then came another heathen invasion. The Templars swore to stand by Gray Coat, and forswore themselves after. Bride armed herself, and rode out through the heathen $(16,000$ of them): this is one of the best passages in the minstrel's story. Bride and Orendel met $(1,2,080, s q$.$) , and he recognised her voice, in the battle.$ After that, Orendel told her who he was. 
There is a great deal more of the story; and many things have been passed over in this abstract which belong to the legendary strain in the composition. The story as here represented will be seen to resemble a great many other stories in its use of a common plot-the quest for the princess of a strange land, and the winning of the princess by the fortunate adventurer, who may or may not be, as Orendel is, a youngest son, but who, in any case, is required to do great things before the princess is gained. In the rambling, blundering story there can be no mistake about this: the minstrel has a story to tell, and this is definitely a considerable part of it, and even in its way an interesting story, not worse than some other (more arrogant) professional fiction.

Has it anything to do with the Sunngod or the Culturehero, with Aurvendill the friend of Thor, or Horvendillus the father of Hamlet?

Some scholars think so; but curiously some of those who have taken most pains to prove their case, Müllenhoff and his followers, have thrown over almost all this part of the story as it stands. Going on to the latter part of the German tale (1. 2845), where Orendel is called back to Trier to help his father against besieging enemies, and taking this along with the things that resemble the Odyssey, they have turned the tale of Orendel-which for more than 2,000 lines is taken up with the story of the young king's voyages and travels away from home into the unknown world to win the true princess-into a return story like the Odyssey -a very good story, but not that which the minstrel told in this romance. Orvendill came back to Groa; Orendel also came back, ${ }^{1}$ and the story of his outward

' Aber Alles wird auf einmal klar und gewinnt Sinn und Bedeutung, wenn wir, worauf zuerst Mullenhof hingewiesen hat, die Brautwerbung als eine Jungere Umbildung betrachten: in der urspringlichen Gestalt handelle ss sich nicht un Orendels Brawtfahrt sandern um soine Kiuckkehr. Ir hat Schiff. bruch gelitten, und kommt in elender Kleidung zuritk in die Heimat, findet seine Gattin van Freiern umlagert, besiegt sie alle, bleibt aber zunilchst 
voyage, it is argued, is not the authentic story. It is made up out of ready-made stuff. The cloggy water, the Lebermere, for example, is a "machine," and a favourite one, in the popular romances and in popular literature generally ${ }^{1}$ and Ise the fisherman is found in the German poem of St. Oswald.

Thus, on one side there is a theory which makes a German Odyssey out of the old book-a story that is not told in the book as it stands. On the other side is a criticism of the work which attaches no importance to the things taken up by the first party, and considers that the positive substantial groundwork is that legendary interest which the first party would neglect as adventitious. Both sides-the mythologists, who would like to see Orendel restored to his own as a demigod at least, identified with Aurvendill; and also the more positive critic, who takes what is before him, and does not choose to say "return of Ulysses" where the book says "outward bound"-are agreed in making little of the story as it is given in the first part of the poem, the part described above; the one side because it is not what they wish to find, the other because it seems to them poor stuff and mere mechanical invention and composition.

Thus this ancient piece of hack-work may serve as an illustration of different methods and tempers of criticism. Poor enough in itself, it is a pretty subject for the game.

It raises some rather large problems, which are likely to recur wherever literature touches, as it perpetually must, on the ground of mythology or folklore.

When the same plot is found in different stories, in what sense is it the same? The question has been heard before

unerkannt, und erst nachdem er sich Land und Leute zuruckgewonnen, der Gnttin Treue wicderholt erprobt und diese ihm sogar im Kampfe siegreich beigestanden, giht er sich als IIerr und Konig zu erkennen, und die Mannen huldigen ihm. (Berger, Orendel (1888), p. Ixxi.)

'Herzog Ermst, ed. Karl Bartsch, p. cxlv. (Berger's geference). 
in this Society; but it has to be asked with a difference in each several case, especially when the stories compared are not of the same order,-when, for instance, one of the examples is taken from Grimm or Campbell, or some such record of oral tradition, and the other from professional or rhetorical literature.

When romantic literature is brought into comparison with stories of popular tradition, there is always the difficulty of deciding where resemblances are evidence of direct obligation or affinity, and where they are coincidencesdue not directly to any one form of a popular story, but indirectly to the common imaginative machinery and properties which go free over all the world unattached to any particular plots. The story of Orendel's wanderings is like the plots of a number of popular tales, but it is not to be identified straight off with any of these, because there is always the possibility that the author may have used, not a particular definite story, but merely the more generic type of adventures, such as might come into anyone's head, combining in his own way the obvious and commonplace motives of an adventurous journey in such a way as accidentally or coincidentally to make something like the plot of a well-known class of märchen.

The case of Orendel may be compared with others in which there is no doubt that a romance has used a definite traditional plot; for example, the romance of Walewein as compared with the Gaelic popular tale of Mac Iain Direach, ${ }^{1}$ or again the romance of Sir Amadas, which is the story of the Travelling Companion, the Grateful Ghost, and which contains not merely the common motive of the dead man returning to help his benefactor, which might possibly be invented independently by different authors, but the particular incidents that belong to this story in tradition, the almost inseparable accidents of a definite and coherent story-formula. It does not seem a priori necessary that 


\section{Notes on Orendel and other Stories.}

the Travelling Companion, at the end of the story, should exact the half of all that the adventurer has gained, even to the dividing of his wife or child; but this ordeal is part of the plot all over the world, ${ }^{1}$ and it is found in Sir Amadas as it is found in scores of other places, - for instance, in the admirable version published the other day by $\mathrm{Mr}$. Larminie. ${ }^{2}$ Here the coincidence is not due to accidental shuffling of commonplaces; it is one identical story which survives and holds the same elements in combination.

On the other hand there is a pretty instance of the way common adventures may be put together independently in similar order, in the French romance of Durmart le Gallois

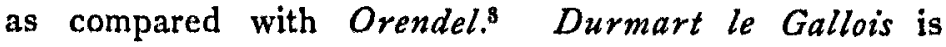
work of a higher class than Orendel; but its author is also a professional story-teller working up the commonplaces of a romantic school. He tells in his own way the story of a King's son and his love for a princess he has never seen, a Queen in Ireland, and of his wanderings in search of her, and how he finds her besieged in her city (Limerick), and takes command of the defence and raises the siege, while the Queen looks on from the battlements. The poem has other merits besides its plot; it is one of the best of the romances of the school of Chrestien of Troyes, and very successful in its choice of motives, especially in its rejection of the unnecessary conventional machinery of dragons, enchanters, and so on. It would have been passed by the curate and the barber with no more censure than they gave to Tirant the White, which it anticipates in some respects as a work of edification and an exposition of the chivalrous ideal. The story is of less

' Max IIippe, Iterrig's Archiv, lxxxi., Untersuchungen zur mittelengl. Romanec von Sir Amadas.

- West Irish Folk-tales and Romances (1893), p. 155 ; the original Irish in Appendix, p. 245.

Ed. Stengel, Strassburg, 1873 . 
importance in Durmart le Gallois than the moral; and the story can hardly be regarded as anything but an arrangement of quite common and familiar material. It is not like Sir Amadas or Walezein, a romantic version of a definite coherent traditional plot.

The story of Durmart is the story of Orendel, in the main. If the story of Orendel (i.e. that part of it which has been abstracted above) is anything but a repetition of commonplaces, if there is in it any specific scheme of a story analogous to the definite plot of Sir Amadas, that must be proved by consideration of the particular details, e.g., the Klebermere, the helping fisherman.

The sluggish sea is a commonplace of popular knowledge in the Middle Ages; ${ }^{1}$ it might easily be put in or left out by any story-teller. But in other stories of the search for the princess there recurs a similar hindrance of the adventurer. One of the stories referred to by Rydberg is that of Alf and Alfhild in Saxo, where Alf in his search for Alfhild has his ships frozen up-densatis aquarum coactibus tanta glaciei moles naves corripuit, ut eis nulla remigandi vis processum struere potuisset."

The King's Son of Ireland, in his voyage to find the unseen princess, the daughter of the King with the Red Cap, is hindered by "druidic mist." So that the Klebermere in Orendel is either part of an original story, or else a coincidence with a common story-formula, and in either case worth noting.

The fisherman Ise also appears in the right place if the story is compared with some others in which the hero is bound on a similar quest. Here again coincidence is easily acceptable as an explanation. Given the idea of any quest, it folluws naturally that the adventurer should find helpers as well as obstacles by the way. At the same time

'Bartsch, 1. c..

2 vil., p. 229, Ilolder.

"MacDougall, Folk and Hero Tales from Argyllshire (1891), p. $15 \mathrm{x}$. 


\section{Notes on Orendel and other Stories.}

it is worth while to consider the other alternative-the possible survival of a definite plot in Orendel. The Argyllshire tale is the nearest in this case (it is remarkablc that it has also, like Orendel, been found to recall the Odyssey in some of its incidents) : the King's Son of Ireland is helped on his way by three mystcrious helpers, one of them an old man of the sea, who goes back to his whale-fishing when the quest is over.

In Curtin's story of The White-bearded Scolog ${ }^{1}$ the King tells his son to find a bride for himself, and a druid names the incomparable lady, to whom the King's son is directed by three giants who are won over to his side.

It is not too much to suppose that the gray coat, the horse and shield, which Orendel receives from his rather unpromising helpers, may have belonged to an original scheme, and that it was a fairy coat of darkness which gave the professional minstrel a chance of working in the legendary interest of the Holy Coat of Trèves.

The stories edited by Mr. MacDougall and Mr. Curtin are recent; if it is necessary to find more ancient evidence it may perhaps be found in the story of The Wooing of Emer ${ }^{2}$ where Cuchulainn is helped on his way by the gift of the whcel that carries him over the freezing plain, and the apple that rolls before him through the field of spikes.

It is time to put things together, though it may not be easy. It is possible, however, to make some sort of classification of stories that more or less resemble Orendel. Taking as the common element the winning of a princess, who is unknown to the adventurer at the outset, we may distinguish the following types of story as among the commonest:-

1. The quest begins as a quest for something else, not for the fairy princess. The princess appears at the end of a series of difficulties, and is carried off along with the

I Hero Tales of Iraland (1894), p. I63.

"Kuno Meyer, in Archicological kiev, vol. i., p. 298; Rewue Celtique, vol. xi., p. 447. 
Golden Fleece, or the Golden Bird, or the Glaive of Light, as the case may be. For example: Fason, Mac Iain Direach (Walewein). Huon of Bordeaux (the romantic second part of the story,) might be studied in this connection.

2. The adventure from the very first is a voyage in search of the unknown Queen, as in Orendel (the first part), and in Durmart le Gallois, in König Rother, Kulhwch and Olwen, Svipdag and Menglad. Stories of this type might be classified according to the way in which the adventure begins. In one variety the mere renown of the peerless lady is enough. In some stories the beginning is in the snowwhite, blood-red incident-Conall Gulban, \&c. In many, the beginning is a malignant commission from a stepmother or some other enemy-Kulhwch and Olwen, Svipdag and Menglad, Hjdlmters Saga. Here of course, there is a cross division, for the malignant injunction belongs to Fason and to other stories of that class, to Huon (whose relation to folklore has not yet been fully discussed), and to Mac Iain Direach-not, it may be remarked, to Walewein.

Apart from both these main varieties, it might be possible to reckon another, where the motive is deliverance of the lady from her oppressors, rather than the winning of the lady by her adventurous wooer: Hr. Tönne, and other northern ballads, Guinglain, Rapunzel; ${ }^{4}$ but it is plain that in these cases it depends on the choice of the storyteller where the interest shall lie, and that this is rather a

1 These three are all compared by Grundtvig, Danske Folkeviser, No. 7o, in connection with the ballad of Sveidal or Svendal, the ballad version of the story of Svipdag.

"Grunulvig, Danske Folkeviser, No. 34.

- Guinglain, or (In the English version) Lybeaws Desconws: see the account by M. Gaston Paris, in Hist. litt. de la France, xxx.

- Grimm, Märahen, No.12. The story of Rapunzel has received its pocti. cal interpretation from Mr. William Morris; its resemblance to the story of Syritha in Saxo (vii., p. 225) seems to deserve consideration from mytholo. gists. 


\section{Notes on Orendel and other Stories.}

variety of emphasis in the rendering than of constituent elements in the matter.'

The story of The Wooing of Emer has an arrangement of the incidents different from those already named. Cuchulainn has met Emer before setting out on the adventures which seem to correspond to those of Kulhwch and other heroes.

The first part of Orendel agrees with many of these stories; and a comparison of them might lead to the conclusion that Orendel is based upon a definite traditional story which keeps together certain definite constituents. Then Orendel (in the first 2,000 lines) would be a romantic literary version of one popular tale, just as Walewein is of another and Sir Amadas of a third. It may be remarked that these three romances give examples of three varieties of quest. Walewein has been noted above; and in the story of the Travelling Companion (Sir Amadas) the deliverance of a princess from an enchanter, or, as an alternative, the winning of a princess from rival suitors, is obligatory. In the Orendel type, as it may be called provisionally, the sequence of events is this--

I. The King's Son goes out to win the unknown $Q u e e n$, on the report of her excellence.

2. He is hindered on the way in the sluggish sea: compare Alf (Saxo), King's Son of Ireland (MacDougall).

3. He is helped by uncouth helpers: compare Emer, Scolog, Red Cap, Hjalmter.

4. He rescues the Queen from her besetting enemies.

The common incident-common to the Fason variety and

3 The most famous of all such tales, the story of the rescue of Guinevere from her captor Mclwas (or Melengraunce), is the most remarkable example of this change of interest, if it was in this story first of all that Lancelot, the rescuer, came to be represented as the lover of the queen See fiomanio, $x$. (M. Gaston Paris on the story of Lancelot in Chrestien's Chevalier do la Charrette, \&c.) It is shown that some of he versions of this story, e.g., the first part of Malory's version-Morte DArthur, xix., 1-9-know nothing of the love of Lancelot and the queen, and that the Lancelot of all later romantic tradition, the lover of Guineverc, is first known to Chrestien of Troyes. 


\section{Notes on Orendel and other Stories. 301}

the $K u l h w c h$ variety - that the bride has to be won from her father against his will, is wanting here.

It is quite possible that the resemblances between $O$ rendel on the one hand, and Tochmarc Emer, Kulhwch, Svipdag, Alf, Walezein, Conall Gulban, \&c., on the other, may be mere coincidence, such as appears to be the case in Durmart le Gallois. The medieval romancer works with a few commonplace properties, and it is nothing to be wondered at if they fall into similar patterns at different times. There may be nothing more in Orendel (in this part of it, that is) than the repetition of mechanical stock devices.

If there is anything more than this, if there is an old story at the foundation of this romance, what are its bearings on mythology? And is there any room for Aurvendill, Earendel?

Mr. Rhys (Hibbert Lectures) takes Tochmarc Emer together with Kulhwch and Olwen as stories belonging to the Sun-god and compares them with Frey and Gerd in the "Elder Edda." If Frey and Gerd be admitted in this comparison, there can be no good reason for excluding Svipdag and Menglad, the resemblance of which to Kulhwch is pointed out, and not exaggerated, by Grundtvig.

It may be that Aurvendill is really the hero of the German romance of Orendel-that is, it may be that the Svipdag story was sometimes told with Aurvendill as the name of the hero, a different story from that of Aurvendill in the basket, and his frost-bitten toe. Aurvendill, whose solar character seems to be proved by the Old English connotation of Earendel, then comes in for the solar interpretation along with Cuchulainn, Kulhwch, Frey and Svipdag, and helps to corroborate that interpretation for the other names and the stories to which they belong. This is possible; but "it is out of my welkin."

Whatever the solution may be, the older, more mythological, or apparently mythological, stories of the quest 


\section{Notes on Orendel and other Stories.}

and the winning of the unknown princess-Olwen, Gerd, Menglad-cannot be separated from the more popular stories. It is another case of the "Far-travelled Tale" as stated by Mr. Lang; it is a variety of the story of Jason. The expeditions of Cuchulainn, Kulhwch and Svipdag, must be considered along with The King's Son of Ireland and The daughter of the White-bearded Scolog, and all the other märchen of that sort.

Bidding farewell to Orendel for the present, we may look at the three stories referred to by Grundtvig in his note on Svipalag. They bring out in a striking way the difficulties of solar myth where the mythological version has relations with popular fairy-tales. The three stories are those of Svipdag himself, of Kulhwch and of Hjálmter.

The story of Svipdag as given in the Icelandic poems Grogaldr and Fjolsvinnsmal has the following incidents :-

I. The hero is sent under a curse or a spell, by his stepmother apparently, though this is not quite clear, to look for Menglad.

2. He goes to his mother's grave, awakes her from the dead, and gets her blessing on his journey. So far Grogaldr.

3. In the second poem, he has come to Menglad's castle, where he encounters a giant warder, and has a long match at riddles with him before he is recognised as the man of destiny, and is welcomed by Menglad as her deliverer and lord.

In the Danish ballad, Child Svendal, or Sveidal, is sent out by his step-mother to find and win the maiden he has never seen. He goes to his mother's grave, and she gives him a horse that rides over sea and land, a magic tablecloth and drinking-horn, a glaive of light, a ship that will run down anything that comes in the way, and a purse that is always full. He comes to the unknown shore, and finds a shepherd there, who tells him that Svendal is to win the princess. Her castle is of marble stone, the gate is of red gold. 
The locks fall off as he comes near, the lions and bears that keep the gate are harmless, the trees bow to him, the bride's father acknowledges him more readily than Yspaddaden Pencawr in the Welsh story when Kulhwch came wooing.

Kulhwch has a step-mother also, who lays him under a destiny to win Olwen. "I declare to thee that it is thy destiny (mi atynghaf dynghet itt) not to be united with a wife until thou obtain Olwen, daughter of Yspaddaden Pencawr." 1 This was intended to destroy Kulhwch; for Olwen's father, whose name is interpreted "Hawthorn Headgiant," was accustomed to kill all his daughter's suitors. He is like the father of Alfhild in Saxo's story referred to above, like the father of Medea, like the king with the red cap, like the white-bearded Scolog, and a vast number of other fabulous parents, Kulhwch went to King Arthur's court, and came to the giant's land with the help of King Arthur and all his men. There they met a shepherd, the giant's brother, who tried to dissuade them, but in vain; and Kulhwch went on to encounter the dangerous father, and to perform with the help of King Arthur all the tasks prescribed. ${ }^{2}$

Hjalmters Saga, the last of Grundtvig's references, has never, as far as I know, been closely examined in this connection. There is a valuable study of it in relation to the Icelandic rhyming romance on the same subject (Hjálmters Rimur) by Kölbing. ${ }^{3}$ The Saga is one of the later Icelandic romantic Sagas ; professional hackwork again. Its date is uncertain; it is extant in $17^{\text {th }}$ century paper MSS. The Rimur are found in I6th century MSS., and are attributed to one Indridi, who lived at the end of the $14^{\text {th }}$ century. Dr. Jón Thorkelsson is

' Lady Charlotte Guest's Mabinggion, vol, ii. p. 252.

"Rhys, Hibbert Lectures, p, 486, sqq.

- Beitrige sur vergleichenden Geschichts der romantischen l'oesie wnd Pyosa des Arittelalters (1876), p. 200. 


\section{Notes on Orendel and other Stories.}

inclined to accept this date. ${ }^{1}$ Kölbing has compared the prose and the rhyme, and shows that the Saga has been doctored, commonplace adventures having been interpolated-viking and berserk adventures such as have intruded even into the great original Sagas, ${ }^{2}$ and which are very neatly detected and erased by Kölbing here. The Rimur are much more coherent, and are founded on an older and sounder version of the prose romance, which, if the date of the Rimur is accepted, must have been current in the $14^{\text {th }}$ century.

Now this story of Hjálmter, recognised by Grundtvig as resembling Kulhwch and Svipdag, is much nearer than either of the others to the forms of popular story-telling, and in some things very curiously like the forms of Gaelic storytelling in particular. ${ }^{3}$ Hjálmter, like Svipdag (Svendal) and Kulhwch, is put under a destiny by his stepmother: he had rejected her love. Unlike Svipdag or Kulhwch, and singularly like Mac Iain Direach, he answers her spell with another, a counterspell, like that which Mr. Nutt pointed out in his note on Walewein as a property of Celtic story-telling. This instance is more detailed, and the resemblance much stronger than in Walewein. "She says: 'Now shalt thou be paid for the blow thou gavest me: this I lay on thee, never to rest, night nor day, save on ship-board or under awnings, till thou find Hervor, Hunding's daughter.' Hjalmter answered: 'Thou shalt lay nothing more on me, for thy jaw shall stand wide open: and I think little of going to look for a king's daughter. There are high rocks down by the harbour; there shalt thou mount and stand with a foot on one and a foot on another, and four of my father's thralls shall kindle fire bencath thee, and thou shalt live on what the ravens bring, till I come again." "4

1 Om Digtningen paa Ysland $i$ det 15. og 16. Aarhundrede, $p .144$.

- York Powell, Folk-Lore, vol. v, p. 100.

- Sagan af Kjjilmter ok Olver, Rafn, Fornaliar Sïgur, v. ii., pp. 453-518 (1830).

HIjalmeters Saga, p. 479. 
Compare Mac Iain Direach ${ }^{1}$ -

"And his muime took the feather in her hand, and she said: 'I am setting it as crosses, and as spells, and as the decay of the year on thee; that thou be not without a pool in thy shoe, and that thou be wet, cold, and soiled, until thou gettest for me the bird from which that feather came.' And he said to his muime: 'I am setting it as crosses, and as spells, and as the decay of the year on thee; that thou be standing with the one foot on the great house, and the other foot on the castle; and that thy face be to the tempest whatever wind blows, until I return back.'"

Hjalmter went out on his journey, with his friend Olver and a mysterious swineherd, Hord, who helps him through his troubles. There are two other helpers, one a trollwife, Skinnhufa, and the other a fingálkn, a kind of sphinx, named Vargeysa; and there are magic swords also, as in Svendal and (allusively) in Svipdag. Hervor is found at last, and greets Hjálmter: her father Hunding is more like the Welsh father than the amenable heathen king in the Danish ballad. There are tasks before the princess is won, as in Kulhwch; a bull to tame, a wrestling match, and a tug of war over a fire. The end is that of a Fason story transferred to Lat. $70 \mathrm{~N}$. : the father pursues the ship in the form of a walrus; and then there is a very neat piece of tactics-" Hord said: "That is the being I like least, but there is nothing for it, fosterbrother, thou shalt have aid; but see thou name me not while he is here, or I die.' Then he lays him down in the hold, and they put clothes over him." Hord, that is, goes to sleep in the manner of the Finns, and sends himself off in another shape against the walrus. "They saw a narwhal shoot from under their ship at the walrus, very sharply, and fall on him." Hervor likewise changes her shape; and the other two helpers, Skinnhufa and Vargeysa, come as eagles, and Hunding is killed.

The explanation of Hord is that he is the brother of

I Camplell, West IIighland Tales, vol. il., p. 328.

vol. vill. 


\section{Notes on Orendel and other Storics.}

Skinnhufa and Vargeysa; they had all been bewitched by their stepmother, who had a well occupied life, for she went and became IHjálmter's stepmother after that. She had been left on the rocks, as before described, and she fell into the fire when he came back, like Mac Iain Direach's stepmother also. There is a curious avoiding of the right end in Hjalmter (both in Saga and Rimur), for Hjalmter marries one of Hord's sisters, and Hervor is married to Hord. Kölbing notes that this can hardly have been the original conclusion, and it is easy to agree with him.

In many things this story is more like Mac Iain Direach and Walewein than Svipdag or Kulhwch; and the crosses and spells reopen, in a very interesting way, the question of the relations of Gaelic and Icelandic literature. Hord takes the place of the fox who in the Gaelic story and in the Dutch romance is a prince bewitched, and recovers his own at the end of the story. But the resemblance to Svipdag and Kulhwch is still considerable; and Orendel, to come back to the starting point, is not quite out of it either. In Hjalmter, however, though there is a pretence of romantic literary form, that is not enough, any more than in Walewein, to conceal the essentially popular character of the story.

The story of the princess over-sea is one that may be taken up by almost any kind of poet or storyteller. In one of its forms it has become a new myth, a myth for all modern poets from Petrarch to $\mathrm{Mr}$. Browning and Mr. Swinburne. The story of Jaufre Rudel and the Lady of 'Tripoli has been studied by M. Gaston Paris, ${ }^{1}$ and shown to have its origin in some verses of the Provençal poet which were misunderstood by his biographer, or by the tradition which his biographer wrote down. The story of Jaufre Rudel's last voyage is a myth, growing out of the same common-place romantic fiction which is used by the author of Durmart le 
Gallois, a common-place fiction grafted on a misinterpreted poem. Orendel and Durmart le Gallois, Kulhwch and Svipdag, and the King's Son of Ireland are variations on the sane theme, the product of different orders of imagination and expression. The story of Jaufre Rudel has had infinitely deeper meaning, and infinitely more honour, than any of these. It does not diminish either its imaginative meaning or its honour among poets and their hearers, to know how the story arose; but possibly the history of this myth, a history which has been accurately worked out, may have some bearing on the problems of older myths and symbolisms. It proves that the religious or mythological import is not necessarily the beginning of the story.

\section{SOME OXFORDSHIRE SEASONAL FESTIVALS:}

WITH Notes on MORRIS-DANCING IN OXfordSHIRE.

Dy J'ercy Manning, M.A., F.S.A.

(Read at meeting of $\mathrm{x} 6$ th March, 1897. )

Under this title I have described typical instances of village feasts in Oxfordshire which illustrate the observances now or formerly in vogue on three of the seasonal festivals, May Day, Whitsuntide, and the Lamb Ale.

I must express my obligation to Mr. T. J. Carter of Oxford, who has been invaluable in collecting information for me, and to Mr. C. Taphouse of Oxford, who kindly reduced to writing the airs of the songs from Bampton.

$$
\text { May Day. }
$$

Bampton-in-the-Bush is a small town about three miles 